УДК 349.22

DOI https://doi.org/10.32837/pyuv.v0i5(34).652

\author{
Д. О. Плехов \\ orcid.org/0000-0002-6465-7111 \\ аспірант кафедри трудового права \\ Національного юридичного університету імені Ярослава Мудрого
}

\title{
ДИСТАНЦІЙНА ЗАЙНЯТІСТЬ ЯК ОДНА 3 ФОРМ ТРУДОВИХ ВІДНОСИН В УМОВАХ СЬОГОДЕННЯ
}

Постановка проблеми. Покращення показників якості життя населення України та наближення їх до європейських стандартів потребує інтенсивного розвитку економіки нашої держави на основі посилення ï̈ конкурентоспроможності. Динамічний соціально-економічний прогрес має базуватися передусім на розвитку та ефективному використанні найціннішого ресурсу сьогодення - трудового потенціалу суспільства та посиленні його інноваційної активності.

У результаті розвитку науково-технічного прогресу та розширення ринку праці, в тому числі й у рамках міжнародного співробітництва, набуло актуальності таке явище, як дистанційна робота. Тематика залучення дистанційного працівника для виконання певного роду робіт надзвичайно актуальна. У подібних відносинах мають інтерес як люди різних професій, які зазичай не зацікавлені в жорстких формах співробітництва з організаціями, так і різного роду компанії, які відчувають необхідність у залученні фахівців, але не бажають зв'язувати себе довгостроковими формами співробітництва. У подібних відносинах заінтересовані обидві сторони, й інтерес кожної зумовлений своїми уявленнями про корисність.

В умовах глобалізації такий вид діяльності дозволяє дистанційним працівникам оминути всі кордони і працювати як у своїй країні, так і виконувати замовлення зарубіжних замовників, що часто платять більше. Крім того, у зв'язку зі спалахом COVID-19 суттєво збільшилися ресурси для запровадження дистанційної роботи як організаційного заходу фізичного дистанціювання, що має на меті запобігання зараженню коронавірусом на робочих місцях. Отже, дистанційна зайнятість потрібне явище як в умовах економічної кризи, так і в умовах скорочення попиту на робочу силу.

Мета статті - дослідити дистанційну зайнятість як одну із форм трудових відносин в умовах ринкової економіки, зокрема розглянути актуальні питання сьогодення, на підставі чого зробити певні висновки.

Аналіз останніх досліджень i публікацій. Проблематика правового регулювання дистанційної зайнятості працівників була в тій чи іншій мірі предметом вивчення різних учених, 3-поміж яких варто виділити таких як Н.Б. Болотіна, В.С. Венедіктов, Л.П. Гаращенко,
В.В. Жернаков, С.А. Іванов, М.I. Іншин, I.Я. Кисельов, В.П. Кохан, А.М. Курінний, В.В. Лазор, Л.I. Лазор, А.М. Лушніков, В.М. Лушнікова, P.3. Лівшиць, М.М. Моцар, В.I. Прокопенко, В.Д. Перевалов, П.Д. Пилипенко, М.А. Шабанова, О.М. Ярошенко та ін. Проте, не применшуючи значення наукових доробків зазначених науковців щодо дослідження вказаного питання, тематика правового регулювання дистанційної зайнятості працівників і сьогодні є досить актуальною.

Виклад основного матеріалу. Коли основними факторами розвитку стають новітні інформаційні технології з їх стрімко зростаючим потенціалом і швидким падінням витрат, відкриваються великі можливості для появи нових форм організації праці й зайнятості в рамках як окремих підприємств, так і суспільства в цілому. Перехід до інформаційного суспільства, яке продовжує формуватися на межі змін у комунікаційних технологіях і в мотивації трудової поведінки людей, зумовлює істотні трансформації трудових стосунків, а саме появу «дистанційних стосунків» між роботодавцем і його співробітниками, які є частиною процесу децентралізації трудової діяльності в просторі й часі, тобто процесу формування гнучкого ринку праці. Наразі масштаби й темпи поширення дистанційної занятості дуже високі, особливо у зв'язку зі спалахом COVID-19.

Слід зазначити, що до пандемії відносно незначна частина населення у світі працювала дистанційно на постійній основі. Так, за оцінками МОП, $8 \%$ світової робочої сили, або приблизно 260 мільйонів працівниць, постійно працювали вдома до пандемії COVID-19. Для країн ЄC у 2019 році частка дистанційних працівниць у віці 15-64 років становила лише трохи більше $5 \%$ і залишалася такою протягом останнього десятиліття; щоправда, дещо зросла частка тих, хто іноді працювали удома: з $6 \%$ у 2009 році до $9 \%$ у 2019 році (Євростат). За даними Євростату, серед країн-членів ЄС найбільшу частку віддалених працівниць мали Нідерланди та Фінляндія (14\% зайнятих людей, які зазвичай працювали з дому у 2019 році), за ними йдуть Люксембург та Австрія (де $12 \%$ та 10\% відповідно). Станом на 2018 рік близько $24 \%$ усіх працюючих американок працювали віддалено принаймні частину часу (за даними Федерального бюро статистики праці), але 
регулярно працювати віддалено у США мали змогу лише 7\% працівниць (згідно з проведеним у 2019 році Національним обстеженням про компенсацію (NCS) Федерального бюро статистики праці).

Загалом же, за даними дослідження Global State of Remote Work (Owl Labs, 2018), лише трохи більше половини (56\%) компаній у всьому світі станом на 2018 рік передбачали для співробітниць можливість виконувати роботу дистанційно хоча б в якійсь формі. Важливим розрізненням тут $€$ те, що до пандемії вдома працювали переважно самозайняті особи. За оцінками МОП, лише 19\% тих, хто постійно працювали вдома до пандемії COVID-19, були найманими працівницями; у ЄC серед найманих працівниць таких було лише $3 \%$, натомість частка працюючих удома самозайнятих послідовно зростала, сягнувши 19\% у 2019 році.

Натомість пандемія очікувано змінила ситуацію. Так, у розпал пандемії в березні-квітні у тій чи іншій мірі вдома працювали дві третини $(62 \%)$ усіх працюючих у США (згідно з панельними даними Gallup). У країнах ЄC ці показники були дещо меншими, проте різниця із ситуацією до пандемії є значною. Так, в аналогічний період у Німеччині та Угорщині в тій чи іншій мірі роботу вдома виконувала чверть усього зайнятого населення, а в Чехії та Польщі таких працівників була майже третина.

Щодо України сучасний етап їі розвитку окреслюється також нестримним розвитком трудових відносин, членством у глобальній фінансовій системі, що у свою чергу відображається в соціальних, економічних та інших процесах. Науково-технічний розвиток, вплив та досвід більш високорозвинутих країн Заходу дає поштовх для швидкого розвитку різноманітних форм зайнятості. Зокрема, це й стосується дистанційної зайнятості, яка останнім часом набуває все більшого розповсюдження. За даними дослідження Соціологічної групи «Рейтинг», станом на березень $29 \%$ дорослого населення України працювало дистанційно; серед користувачів Інтернету (таке дослідження проводила агенція DigData) частка працюючих удома була дещо вищою - $31 \%$. У квітні серед жителів українських міст із населенням понад 50 тис. працювали з дому неповний чи повний робочий день уже $40 \%$ (за даними опитування Gradus) [1].

В актуальних дослідженнях та дискусіях про дистанційну працю лунають як аргументи щодо переваг, так і щодо недоліків або проблем, пов'язаних із виконанням праці поза робочим місцем. На думку M.I. Іншина, дистанційна зайнятість працівників є надзвичайно потрібною формою трудових відносин в умовах ринкової економіки. Дистанційна зайнятість несе позитивні зміни як для окремих громадян, так і для суспільства в цілому, сприяє розвитку нових форм трудових відносин, стабілізації економіки, підвищує рівень життя населення.

До переваг такої форми зайнятості працівників, як дистанційна, науковець відносить такі: 1) здійснення трудової функції у віртуальному середовищі з використанням інформаційних та комунікаційних технологій; 2) гнучкий графік роботи, що означає можливість оптимізації робочого часу, а також самостійного визначення працівником часу відпочинку; 3) вільний вибір робочого місця та спокійна робоча обстановка, яка включає в тому числі й зменшення ймовірності конфліктів з колегами і (або) керівництвом та можливість вирішення сімейних проблем, наприклад у разі необхідності здійснення догляду за дітьми; 4) економічні фактори, зокрема скорочення витрат на поїздки на роботу чи на харчування; 5) можливість роботи без укладання довгострокового трудового договору, в разі небажання зв'язувати себе тривалими формами співробітництва як працівником, так і роботодавцем [2].

У свою чергу 0.0. Муравйова позитивними рисами розглядуваної форми зайнятості називає: по-перше, це об'єктивна потреба окремих категорій працівників у працевлаштуванні, для яких повна зайнятість з якихось причин скрутна або небажана (працівники похилого віку, матеріодиначки, безробітна молодь без професійних навичок та ін.). Дистанційна зайнятість дозволяє працівникам поєднувати роботу за наймом з виконанням сімейних обов'язків, участю в громадському житті, підтриманням здоров'я тощо. По-друге, така зайнятість продиктована об’єктивною потребою ринку в мобільній робочій силі, викликаній глобалізацією, децентралізацією й спеціалізацією виробництва, а також появою нових технологій. Зайнятість фахівців у галузі інформаційних технологій має за визначенням гнучкий характер [3, с. 46]. Погоджуємося 3 позицією вченої, що дистанційна форма зайнятості працівників мала об'єктивні причини для виникнення і подальшого поширення, являючись одночасно і потребою сфери трудових відносин, і потребою працевлаштування окремих категорій працездатного населення.

Як зазначає М.М. Моцар, дистанційна форма зайнятості веде до мінімізації витрат роботодавця, в тому числі на офісні приміщення, на організацію робочого місця, проходження різних медоглядів, курсового навчання, забезпечення соціального пакета тощо. При цьому роботодавець отримує більш ефективного співробітника, великий вибір персоналу, доступність технологій, дешевизну телекомунікаційної техніки (електронна пошта, дистрибутивний канал для ділової інформації) тощо [4, с. 124]. Як бачимо, наведена позиція висвітлює позитивні ознаки 
дистанційної зайнятості працівників в аспекті роботодавця й одночасно показує негативні риси такого виду працевлаштування для робітника (організація робочого місця за власні кошти, відсутність соціального пакета). Тому важливо визнати, що одночасно з можливостями, які вона створює, дистанційна робота також може ставити перед працівниками та роботодавцями серйозні виклики, які необхідно належним чином вирішувати шляхом структурування, формулювання та впровадження законодавства та політики.

Основні негативні риси поширення дистанційної зайнятості, не лише в Україні, а і в інших державах, пов' язані насамперед з відсутністю або зниженням соціального захисту, гарантій трудових прав працівників, з браком перспективи професійного розвитку, оскільки роботодавець не зацікавлений вкладати кошти в підвищення професійної кваліфікації працівника. Зокрема, А.М. Лушніков та М.В. Лушнікова до соціальних витрат нестандартних форм зайнятості відносять обмеження в доступі до отримання соціальних виплат і послуг (пенсії, медичне обслуговування, оплата днів хвороби) [5, с. 250, 251].

На підставі вищезазначеного хотілося б навести низку позитивних ознак дистанційної роботи як для працівника, так і роботодавця. Серед цих рис для працівника можна виділити такі: (1) відсутність витрат часу і коштів на проїзд до місця роботи; (2) можливість виконання трудової функції у зручний для працівника час, у тому числі перебуваючи у відпустці (щорічній або по догляду за дитиною) чи на лікарняному; (3) можливість самостійного вибору тактики виконання завдань, поставлених роботодавцем; (4) зручність для інвалідів, пенсіонерів, багатодітних жінок, тобто тих категорій громадян, кому складно знайти роботу. Для роботодавця дистанційна зайнятість дає такі переваги: (1) суттєва економія коштів на створення робочих місць; (2) скорочення накладних витрат; (3) оптимізація людських ресурсів.

Для того щоб розширити «кут зору» на проблему дистанційної зайнятості в Україні, вважаємо за необхідне навести негативні ознаки нестандартної зайнятості, які на відміну від позитивних будуть спільними для працівника та роботодавця. До негативних можна віднести: (1) складності кадрового діловодства, атестації; (2) переведення та звільнення віддалено працюючого співробітника; (3) наявність ризиків невиконання роботи; (4) брак механізму захисту комерційної таємниці, можливість перехоплення або втрати даних, переданих через Інтернет; (5) неможливість контролю робочого часу та часу відпочинку працівника, дотримання ним норм охорони праці, санітарно-гігієнічних норм тощо; (6) невизначеність статусу дистанційного працівника i, як наслідок, його правова й соціальна незахищеність [6].
Хоча сьогодні вже й прийнято ряд законодавчих змін, які регламентують порядок установлення дистанційної роботи як на загальних підставах, так і в період загрози епідемії, втім питання правового регулювання трудових відносин 3 дистанційними працівниками в Україні залишається досить проблемним. Нездатність регулювати зайнятість дистанційних працівників обмежує їхню самостійність, гідність і захищеність. Зокрема, до основних правових проблем дистанційної зайнятості, на нашу думку, слід віднести: (а) неврегульованість даного питання відповідно до потреб суспільних відносин; (б) проблему укладення трудового договору, його форми та змісту за дистанційної зайнятості; (в) проблему забезпечення рівності прав дистанційних працівників з іншими працівниками; (г) проблему дотримання вимог щодо охорони праці дистанційними працівниками; (д) проблему визначення місця роботи; (е) проблему захисту інформації; (є) проблему встановлення та обліку робочого часу та його оплати; (ж) проблему поєднання дистанційної форми праці з іншими видами зайнятості; (з) проблему участі дистанційних працівників у профспілкових організаціях; (и) проблему стимулювання розвитку дистанційної зайнятості.

Отже, дана проблема потребує нагального адекватного правового регулювання, здатного забезпечити гідний соціальний захист дистанційних працівників. Глобальна пандемія та карантинні умови показали затребуваність дистанційного формату роботи. Переконані, що така форма професійної діяльності в довгостроковій перспективі буде лише набувати популярності, відповідно, це питання вимагає додаткового законодавчого врегулювання.

Висновки. Підводячи підсумок вищевикладеному, слід констатувати, що в умовах сьогодення, особливо в період пандемії, для держави та суспільства врегулювання відносин у сфері праці має неабияке значення. По-перше, це надасть змогу забезпечити трудові та соціальні права багатьох громадян, які здійснюють чи будуть здійснювати свою діяльність у формі дистанційної зайнятості. По-друге, відповідна реформа матиме функцію як соціального забезпечення працівників, так i фіскальну функцію, оскільки якісна нормативно-правова база у сфері дистанційного працевлаштування сприятиме збільшенню надходжень до державної казни у вигляді податків та єдиного соціального внеску до фондів соціального страхування. По-трете, якісна нормативно-правова база буде стимулом для розвитку малого та середнього бізнесу, які не мають можливості створювати значну кількість робочих місць безпосередньо в офici, проте мають змогу оплачувати заробітну плату працівникам, що здійснюватимуть діяльність безпосередньо вдома з використанням телекомунікаційних мереж. 
При цьому неабияке значення має зарубіжний досвід щодо дистанційної зайнятості, ефективне використання якого на ринку праці України зможе сприяти не лише розширенню національного ринку праці, а й дозволить національній економіці брати активну участь у міжнародному технічному розподілі праці та найбільш повно використовувати переваги від використання такої форми зайнятості. Це дозволить насамперед збалансувати попит та пропозицію на ринку праці України, стати вітчизняній робочій силі більш мобільною, допомогти знайти роботу або додатковий дохід населенню країни. Тому сьогодні важливо забезпечити: гідні умови праці «дистанційним» працівникам; соціальні та правові гарантії роботи; дотримання вимог безпеки роботи; законодавчу регламентацію правил, обов'язків та умов укладання договору з працівниками дистанційної форми зайнятості.

\section{Jimepamypa}

1. Філіпчук Л., Ломоносова Н. Коронавіpyc i дистанційна робота: що зробила держава. URL: https://www.cedos.org.ua/uk/articles/koronavirus-i-dystantsiina-robota-shcho-zrobyla-derzhava

2. Іншин M.I. Види та зміст переваг дистанційної зайнятості працівників в Україні. Теоретичні питання юриспрудениї $і$ проблеми правозастосування: виклики ХХI століття. Харків, 2020. URL: https://pp-ss.pro/wp-content/uploads/2020/06/ $\%$ D0 $\% 86 \%$ D0 $\%$ BD $\%$ D1 $\% 88 \%$ D0 $\%$ B8\% D0 $\%$ BD $\% 20$ $\%$ D0 $\% 9$ C. $\% 20 \%$ D0 $\% 86 . . p d f$

3. Муравьева А.А. Труд, основанный на знаниях: высшая школа и производство (опыт стран ЕС). Труд за рубежом. 2007. № 1. С. 37-58.

4. Моцар М.М. Проблеми формування дистанційних форм зайнятості в Україні. Наукові пращі МАУП 2013. Вип. 2 (37). С. 123-128.

5. Лушников А.М., Лушникова М.В. Курс трудового права : учеб. : в 2-х т. 2-е изд., перераб. и доп. Москва : Статут, 2009. T. 1.879 с.

6. Носенко В.О. Правове регулювання дистанційної зайнятості працівників в Україні : дис. ... канд. юрид. наук: спец. 12.00.05. Київ, 2015. 190 с.

\section{Анотація}

Плехов Д. О. Дистанційна зайнятість як одна з форм трудових відносин в умовах сьогодення. Стаття.

$\mathrm{У}$ роботі досліджено дистанційну зайнятість як одну із форм трудових відносин в умовах ринкової економіки, зокрема, розглянуто актуальні питання, на підставі чого зроблено певні висновки. Зазначено, що в умовах сьогодення, особливо в період глобальної пандемії та карантинних умов, які показали затребуваність дистанційного формату роботи, для держави та суспільства врегулювання відносин у сфері праці має неабияке значення. По-перше, це надасть змогу забезпечити трудові та соціальні права багатьох громадян, які здійснюють чи будуть здійснювати свою діяльність у формі дистанційної зайнятості. По-друге, відповідна реформа матиме функцію як соціального забезпечення працівників, так і фіскальну функцію, оскільки якісна нормативноправова база у сфері дистанційного працевлаштування сприятиме збільшенню надходжень до державної казни у вигляді податків та єдиного соціального внеску до фондів соціального страхування. По-трете, якісна нормативно-правова база буде стимулом для розвитку малого та середнього бізнесу, які не мають можливості створювати значну кількість робочих місць безпосередньо в офісі, проте мають змогу оплачувати заробітну плату працівникам, що здійснюватимуть діяльність безпосередньо вдома з використанням телекомунікаційних мереж.

При цьому неабияке значення має зарубіжний досвід щодо дистанційної зайнятості, ефективне використання якого на ринку праці України зможе сприяти не лише розширенню національного ринку праці, дозволить національній економіці брати активну участь у міжнародному технічному розподілі праці та найбільш повно використовувати переваги від використання такої форми зайнятості. Це дозволить насамперед збалансувати попит та пропозицію на ринку праці України, стати вітчизняній робочій силі більш мобільною, допомогти знайти роботу або додатковий дохід населенню країни. Тому нині важливо забезпечити: гідні умови праці «дистанційним» працівникам; соціальні та правові гарантії роботи; дотримання вимог безпеки роботи; законодавчу регламентацію правил, обов'язків та умов укладання договору із працівниками дистанційної форми зайнятості.

Ключові слова: дистанційна зайнятість, працівник, роботодавець, держава, трудові відносини, зарубіжний досвід.

\section{Summary}

Plekhov D. O. Remote employment as one of the forms of labor relations in today's conditions. - Article.

The paper investigates remote employment as one of the forms of labor relations in a market economy, in particular, considers current issues, on the basis of which certain conclusions are made. It is noted that in today's conditions, especially in the period of the global pandemic and quarantine conditions, which have shown the need for a remote format of work, for the state and society, the settlement of labor relations is of great importance. First, it will ensure the labor and social rights of many citizens who carry out or will carry out their activities in the form of remote employment. Secondly, the corresponding reform will have the function of both social security of employees and fiscal function, as a high-quality regulatory framework in the field of remote employment will increase revenues to the state treasury in the form of taxes and a single social contribution to social insurance funds. Third, a quality legal framework will be an incentive for the development of small and medium-sized businesses, which do not have the opportunity to create a significant number of jobs directly in the office, but can pay salaries to employees who operate directly at home using telecommunications networks.

At the same time, foreign experience in remote employment is of great importance, the effective use of which in the Ukrainian labor market can not only expand the national labor market, but also allow the national economy to actively participate in the international technical division of labor and take full advantage of this form of employment. This will allow, first of all, to balance supply and demand in the labor market of Ukraine, to make the domestic labor force more mobile, to help people find a job or additional income. Therefore, today it is important to provide: decent working conditions for "remote" workers; social and legal guarantees of work; compliance with safety requirements; legislative regulation of the rules, responsibilities and conditions of concluding a contract with employees of the remote form of employment.

Key words: remote employment, employee, employer, state, labor relations, foreign experience. 